\title{
THE TOXINS OF CYANOBACTERIA
}

\author{
Jiři Patočka \\ Purkyně Military Medical Academy, Hradec Králové: Department of Toxicology
}

Summary: Cyanobacteria, formerly called "blue-green algae“, are simple, primitive photosynthetic microorganism wide occurrence in fresh, brackish and salt waters. Forty different genera of Cyanobacteria are known and many of them are producers of potent toxins responsible for a wide array of human illnesses, aquatic mammal and bird morbidity and mortality, and extensive fish kills. These cyanotoxins act as neurotoxins or hepatotoxins and are structurally and functionally diverse, and many are derived from unique biosynthetic pathways. All known cyanotoxins and their chemical and toxicological characteristics are presented in this article.

Key words: Cyanobacteria; Cyanotoxin; Toxicity; Mechanism of action; Water quality; Health risk

\section{Introduction}

Cyanobacteria are a morphologically diverse group of oxygenic photosynthetic prokaryotes, which are phylogenetically closely related to each other and to chloroplasts. Some of them produce considerable toxins. Cyanobacterial evolution began at least 2000 million years ago according to paleontological data. The wide occurrence of toxic Cyanobacteria location in fresh, brackish and sea-water, create problems for all life forms. Organisms responsible include an estimated 40 genera but the main ones are Anabaena, Aphanizomenon, Cylindrospermopsis, Microcystis, Nodularia, Nostoc and Oscillatoria. Cyanobacteria toxins (cyanotoxins) are very often responsible for acute lethal, acute chronic and sub-chronic poisonings of wild and/or domestic animals and humans (7). These bacteria, flourishing in many drinking water resources, are usualy members of the wide spread genus Microcystis, Nodularia or Anabaena, many species of which produce potent toxins. The first published report of the potentially lethal effects of microorganisms known as blue-green algae appeared in Nature in 1878 when Dr. George Francis described an algal bloom that had formed in the estuary of the Murray River, in Australia (16).

The toxins have killed animals, and the consumption of low doses in drinking water is suspected of contributing to a high rate of human liver cancer in certain parts of the world. Most water-based poisonings by cyanobacteria occur when heavy surface growths or scum accumulates near shorelines of lakes, ponds and reservoirs where animals have easy access to toxic levels of cells. Blooms of blue-green algae frequently occur in recreational lakes and rivers used for water sports during the summer swimming season. The cyanotoxins include the neurotoxins - anatoxins and saxito- xins plus the hepatotoxins - namely microcystins, nodularin and cylindrospermopsin. Risk assessment of microcystins indicate that a level of $1 \mu \mathrm{g} . \mathrm{L}^{-1}$ should be considered a maximum allowable concentration (MAC) based upon an

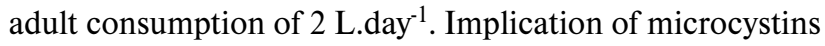
as the major contributing factor in liver failure and death of at least 52 humans, in 1996, at a haemodialysis center in Caruaru, Brazil point to the importance of cyanotoxins as health hazards in drinking waters (20). Since most of the world reservoir and lake based water supplies are subject to increasing nutrient levels, it is probable that episodes of cyanotoxin poisoning will continue unless measures are taken to improve our understanding of their role in water-based diseases.

In this paper the latest informations about all known cyanobacterial toxins of fresh water growing Cyanobacteria are presented.

\section{Cyanobacteria}

Cyanobacteria, also known as blue-green algae, are primitive autotrophic prokaryotes. They have something in common with both plants and bacteria. Like algae, they are photosynthetic and form oxygen during photosynthesis. It is thought that it was these bacteria that were responsible for the first appearance of significant amounts of oxygen on earth about 2.3 billion years ago. Like other bacteria they lack internal organelles bound by membranes. Also like bacteria, they produce a variety of toxins. Cyanobacteria exist in many environments including soil, marine and freshwater. Freshwater lakes and ponds are the sites of the most dramatic blooms of these organisms and are responsible for the death of livestock (and people) in many parts of the world. One well established condition that promotes 
blooms of Cyanobacteria is the relative amounts of phosphorus and nitrogen in the water. Both are required for plant (and cyanobacterial) growth. However, there is an important difference between Cyanobacteria and algae such as diatoms. Some blue-greens can fix nitrogen from atmospheric nitrogen gas. In general algal growth in freshwater lakes is limited by the availability of phosphorus, with plenty of available dissolved nitrogen in the form of nitrate or ammonia. This favours the growth of diatoms and other eukaryotic algae that are good competitors for phosphorus. If the relative amount of nitrogen decreases, resulting in nitrogen limited pond, Cyanobacteria will be favoured because they can fix nitrogen from the atmosphere. The decrease in dissolved nitrogen can occur after a bloom of diatoms, or other algae. The bloom can result in very large standing stock of Cyanobacteria that discolour the water or result in a surface scum. If present, this is a clear sign not to drink or swim in the water because contact with skin can result in itchiness and rash. Recently the biology and ecology of Cyanobacteria are studied intensively (4). The taxonomy of Cyanobacteria is complicated, we used taxonomic scheme based on Rippka et al. (33). Toxicologically important Cyanobacteria are genus Anabaena, Oscillatoria, Microcystis, Nodularia, Cylindrospermopsis, and Lyngbia.

\section{Genus Anabaena}

Anabaena spp. are photosynthesizing, nitrogen-fixing, filamentous and unbranched algae (Fig. 1A) found widely in fresh and salt waters. Any of various freshwater algae of the genus Anabaena sometimes occur in drinking water and cause a bad taste and odour. At present more than thirty species of the genus Anabaena is known (17) but only some of them were studied from the toxicologic point of view.

Fig. 1: Microphotographs of Cyanobacteria genus Anabaena (1A), Oscillatoria (1B), Microcystis (1C), and Nodularia (1D).

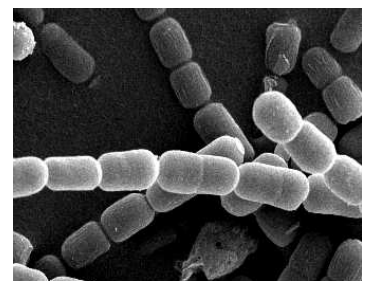

$1 \mathrm{~A}$

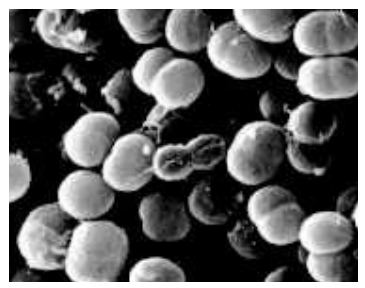

$1 \mathrm{C}$

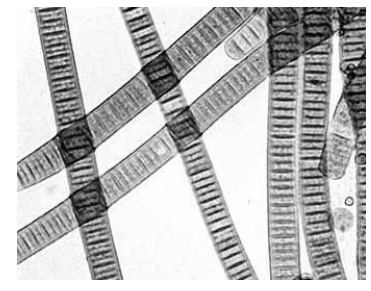

$1 \mathrm{~B}$

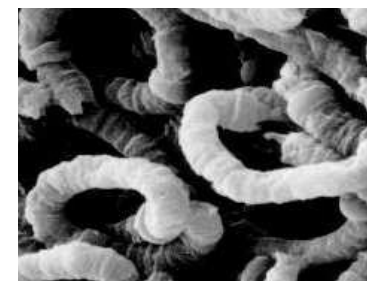

1D

\section{Genus Oscillatoria}

is represented by 16 species (17) of these algae which occurs as a single row of cells called a trichome (Fig. 1B) and which does not produce any spores or heterocysts. The reproductive body called the hormogonium is very difficult to tell apart from the rest of the cells making up the trichome. The hormogonia tends to split off the main body of cells and then drift away to form a new trichome. The main toxic products of genus Oscillatoria are microcystins (3).

\section{Genus Microcystis}

Microcystis spp. is single-celled, colonial, freshwater cyanobacteria (Fig. 1C) and has been identified world-wide. Although many studies have not been able to confirm the species, both $M$. aeruginosa and $M$. viridis appear to be the most common microcystin-producing species. Microcystis spp. had been known for their toxicity for a long time. Since that time approximately 30 different species (17) and 35 different microcystins have been described in these cyanobacteria, primarily from $M$. aeruginosa and $M$. viridis. Microcystis aeruginosa is colonial, which means that single cells can join together in the groups as colonies whose tend to float near the water surface. Colony sizes vary from a few to hundreds of cells. It is common bloom-forming algae found primarily in nutrient enriched fresh waters and lower salinity estuaries. The blue-green alga, Microcystis, occurs widely in Australia, and has caused many cases of livestock poisoning in New South Wales and Victoria $(13,40)$. Cyanobacteria Microcystis ssp. very often determined water quality (9) and may be very dangerous for humans (30).

\section{Genus Nodularia}

is represented by 16 species (17) of filamentous algae (Fig. 1D) occurs in saline and brackish waters and in soil all over the world (41). For example $N$. spumigena blooms have been observed in all areas of the Baltic Sea (38).

\section{Genus Cylindrospermopsis}

At present only one species of genus Cylindrospermopsis, $C$. raciborskii, is known. The geographic distribution of this species first recorded in tropical to subtropical areas is now spread to temperate countries. In November 1979, an outbreak of severe hepatoenterities and renal damage involved 148 people among the Aboriginal population in Palm Island (North Queensland, Australia) (5). A new toxin, cylindrospermopsin, was purified from a $C$. raciborskii strain, hold responsible for the disease (27). Then other toxicity episodes due to $C$. raciborskii were observed in Australian freshwater reservoirs and recreational water (13). More recently, paralytic shellfish poisons were identified in two Brazilian C. raciborskii strains (23).

\section{Genus Lyngbya}

These are filamentous blue-green algae with worldwide distribution throughout tropical and subtropical regions. At 
present the most important species of genus Lyngbya are $L$. majuscula, L. martensiana, and L. aestuarii (17).

\section{Cyanotoxins}

All as yet known cyanotoxins can be divided according to place of theirs toxic effect into neurotoxins and hepatotoxins (29). As neurotoxins are classified anatoxins and saxitoxins and as hepatotoxins are classified microcystins, nodularin, cylindrospermopsin and lyngbyatoxin A. Cyanotoxins are very intensivie studied family of biologically active compounds and finding of other new compounds we can expect in the nearest time.

\section{Anatoxins}

The anatoxins are a group of neurotoxic alkaloids produced by a number of cyanobacterial genera including Anabaena, Oscillatoria and Aphanizomenon. They affect the functioning of the nervous system, often causing death due to paralysis of the respiratory muscles.

As yet three compounds of this type are known, anatoxin-a, homoanatoxin-a and anatoxin-a(s) (Fig. 2). Homoanatoxin-a was firstly prepared synthetically (45), but lastly was discovered in Cyanobacteria, too (15). Anatoxins are perhaps one of the most toxic of the cyanobacterial toxins in this group, since the effects of ingestion can be lethal within 4 minutes, depending on the quantity consumed. This led to the compound dubbed a "Very Fast Death Factor“.

Fig. 2: Chemical structures of anatoxin-a, homoanatoxina and anatoxin-a(s)

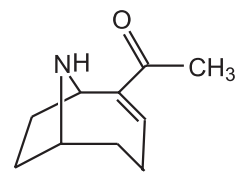

Anatoxin-a

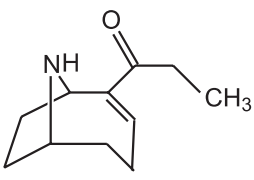

Homoanatoxin-a<smiles>COP(=O)(O)ON1C(=N)NCC1CN(C)C</smiles>

Anatoxin-a(s)
Anatoxin-a is one of the most potent agonists at the nicotinic acetylcholine receptor discovered to date $(24,42)$. Its naturally observed homologue, homoanatoxin-a, has very similar properties. Both act as a mimic of the neurotransmitter, acetylcholine and irreversibly binds the nicotinic acetylcholine receptor (NAChR). Normal neuromuscular action involves the release of acetylcholine, which binds its receptor, leading to the opening of a related sodium channel. The resulting movement of sodium ions produces the action potential causing the muscles to contract. At this point, an enzyme called acetylcholinesterase then cleaves the neurotransmitter, allowing the sodium channel to return to its resting state, and hence the muscle can relax. Anatoxin-a and homoanatoxin-a also binds the NAChR to produce an action potential, but cannot be cleaved by the enzyme. The sodium channel is essentially locked open, and the muscles become over-stimulated and become fatigued and then paralysed. When respiratory muscles become affected, convulsions occur due to a lack of oxygen supply to the brain. Suffocation is the final result a few minutes after ingestion of these toxins.

The mechanism of toxic action of anatoxin-a(s) is different. Compound III is the first organophosphate found in nature and it is a very strong inhibitor of acetylcholinesterase, likely as powerful as some nervous chemical warfare gases (19). The toxicity of these compounds $\left(\mathrm{LD}_{50}\right)$ varies from $20 \mu \mathrm{g}$. $\mathrm{kg}^{-1}$ (intra peritonealy in mouse) for anatoxin$\mathrm{a}$ (s) to 200-250 $\mathrm{g} \mathrm{kg}^{-1}$ for anatoxin-a and homoanatoxin-a.

Despite its poisonous nature, however, anatoxin-a and many related synthetically prepared analogues have found widespread use in medicine and for pharmacological applications. Since it binds the nicotinic acetylcholine receptor irreversibly, it is an excellent means of studying this receptor, and also the mechanisms of neuromuscular action. Its analogues are used to further elucidate the receptor sub-types, and this research may lead to the development of new drugs which have none of the toxicity associated with anatoxin-a itself, but which act merely as acetylcholine replacement candidates. For example, the neurodegenerative disorder, Alzheimer's disease is associated with an inability of neurons to produce acetylcholine. Therefore agonists of NAChR derived from anatoxin-a can be useful therapeutics of Alzheimer's disease.

\section{Saxitoxins}

Like anatoxins, the saxitoxins (STX) are neurotoxic alkaloids which are also known as PSP's (paralytic shelfish poisons) due to their occurance and association with seafood. There are a number of STX variants generally divided into groups based on their structure or organism of origin. The single sulphated STX's are known as gonyautoxins (GTX) and B-toxins, the doubly sulphated STX's are known as C-toxins. There are also decarbamyl STX's (dcSTX) and a group of STX variants, so far found only in Lyngbia wollei, known as Lyngbia-wollei-toxins (LWTX) (28). Chemical structures of the most important saxitoxins are shown in Fig. 3.

Fig. 3: The common chemical structure of saxitoxins. STX = saxitoxin, Neo-STX = neosaxitoxin, GTX = gonyautoxins, $\mathrm{B}=\mathrm{B}$-toxins and $\mathrm{C}=\mathrm{C}$-toxins.

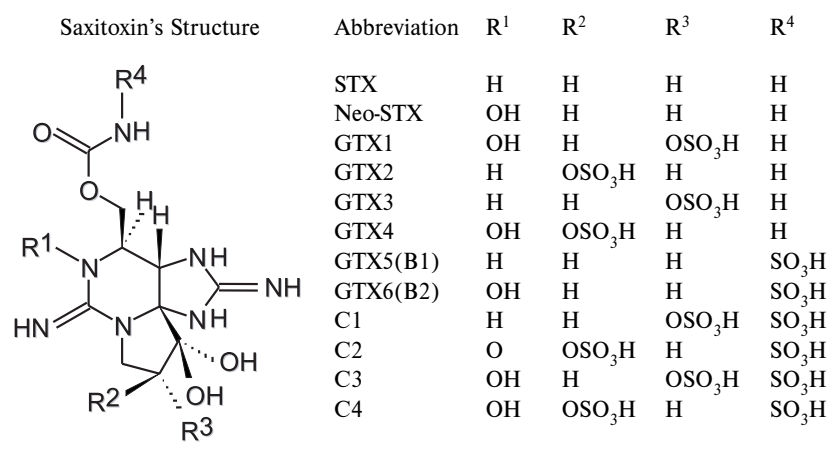


STX was the first known and most studied toxic component of paralytic shellfish poisoning (PSP). This toxin blocks neuronal transmission by binding to the voltage-gated $\mathrm{Na}+$ channels in nerve cells, thus casuing their neurotoxic effects. Although the toxin's mechanism of action is well known at the molecular level, there are still many unresolved questions about its pharmacokinetics and the PSP intoxication syndrome in mammal (1). STX's are highly toxic with $\mathrm{LD}_{50}$ 's as low as $10 \mu \mathrm{g} . \mathrm{kg}^{-1}$ (i.p.) in mice.

\section{Microcystins}

The microcystins are a group of cyclic heptapeptide ( 7 amino acids) hepatotoxins produced by a number of cyanobacterial genera, the most notable of which is the widespread Microcystis from which the toxins take their name. Microcystins consist of a seven-membered peptide ring, which is made up of five non-protein amino acids and two protein amino acids. It is these two protein amino acids that distinguish microcystins from one another, while the other amino acids are more or less constant between variant microcystins. Using amino acid single letter code nomenclature, each microcystin is designated a name depending on the variable amino acids which complete their structure. The most common and potently toxic microcystin-LR contains the amino acids Leucine (L) and Arginine (R) in these variable positions.

There have been approximately 60 different microcystins identified to date. Below is the general stucture of microcystins (Fig. 4) showing the variable amino acid positions "X" and "Y". The amino acids are delineated in this diagram and numbered according to the microcystin standard nomenclature. $\mathrm{R}^{1}$ and $\mathrm{R}^{2}$ are $\mathrm{H}$ in demethylated microcystins (10).

Fig. 4: The common chemical structure of microcystins. Adda $=$ 3-amino-9-methoxy-2,6,8-trimethyl-10-phenyldeca4,6-dienoic acid, D-Glu = D-glutamic acid, Mdha $=$ N-methyldehydroalanine, D-Ala $=$ D-alanine, Masp = D-methylaspartic acid, and $\mathrm{X}$ and $\mathrm{Y}$ are both variable $\mathrm{L}$-amino acids.

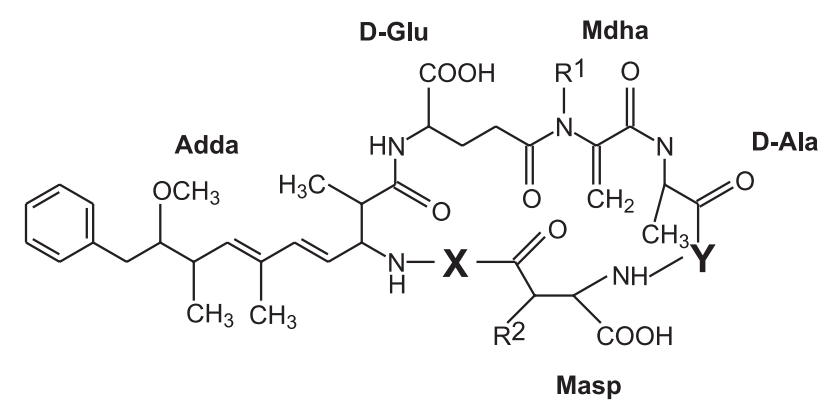

These monocyclic heptapeptides are characterised by some invariant amino acids, including one of unusual structure - 3-amino-9-methoxy-2,6,8-trimethyl-10-phenyldeca-4,6dienoic acid (Adda) - which is essential for expression of toxicity. The Adda moiety is also important in the binding of the toxin to protein phosphatases.

Microcystins are chemically stable, but suffer biodegradation in reservoir waters. The most common member of the family, microcystin-LR ( $\mathrm{L}$ and $\mathrm{R}$ identifying the 2 variable amino acids, in this case leucine and arginine respectively) has an $\mathrm{LD}_{50}$ in mice and rats of $36-122 \mu \mathrm{g} \cdot \mathrm{kg}^{-1}$ by various routes, including aerosol inhalation. Although human illnesses attributed to microcystins include gastroenteritis and allergic/irritation reactions, the primary target of the toxin is the liver, where disruption of the cytoskeleton, consequent on inhibition of protein phosphatases 1 and $2 \mathrm{~A}$, causes massive hepatic haemorrhage. Microcystins are tight-binding inhibitors of these protein phosphatases, with inhibition constants in the nanomolar range or lower. Uptake of microcystins into the liver occurs via a carriermediated transport system, and several inhibitors of uptake can antagonise the toxic effects of microcystins. The most effective of these is the antibiotic rifampin, which protects mice and rats against microcystin-induced lethality when given prophylactically and, in some cases, therapeutically (10). More recent experimental evidence shows that microcystins may also act as liver tumor promoters in extremely small amounts. A tumor promoter does not initiate cancer formation but helps a previously developed cancer to survive. This type of toxin has been shown to persist in water for a week or more after the bloom has disappeared. Poisoning symptoms may take 30 minutes to 24 hours to appear, depending upon the size of the animal affected and the amount of toxic bloom consumed. Microcystin toxicosis may include jaundice, shock, abdominal pain, weakness, nausea and vomiting, rapid and weak pulse and death (3).

\section{Nodularin}

Nodularin is a toxin produced by Nodularia spumigena (32). The structure of nodularin is related to the potent cyclic heptapeptide, the microcystins, but differs in that nodularin is composed only five amino acids in the peptide ring (Fig. 5). Likewise as in microcystins, an atypical amino acid Adda is present in nodularin molecule and also other parts of nodularin are very similar to microcystins. Not only the structures of these two cyanobacteriual toxins are similar. They both show the same hepatotoxic effect through the potent inhibition of protein phosphatases and their toxicity is also similar (46). It is very probably, that on the toxicity of nodularin participate also on their capability to create pores in lipid bilayers of native membrane (39). Other derivative of nodularin, [L-Har2]nodularin, compound with L-homoarginin moiety in molecule, was recently found in freshwater cyanobacteria Nodularia PCC 7804 (2).

\section{Cylindrospermopsin}

Cylindrospermopsin (Fig. 6) is the potent hepatotoxin produced by the freshwater blue-green alga, Cylindrospermopsis raciborskii and Aphanizomenon ovalisporum (37). 
Fig. 5: Chemical structure of nodularin. Adda = 3-amino-9methoxy-2,6,8-trimethyl-10-phenyldeca-4,6-dienoic acid, D$\mathrm{Glu}=\mathrm{D}$-glutamic acid, Mdha $=\mathrm{N}$-methyldehydroalanine, Masp = D-methylaspartic acid, Arg = L-arginine.

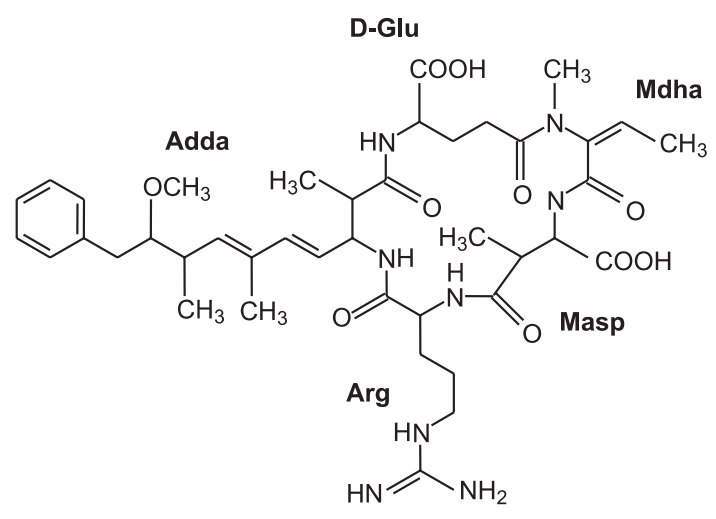

Fig. 6: Chemical structure of cylindrospermopsin.<smiles>CC1C(OS(=O)(=O)O)CC2CC(C(O)c3cc(=O)[nH]c(=O)[nH]3)NC3NCC1N23</smiles>

The results of intraperitoneal and oral dosing of animals show that hepatotoxicity is the main effect of cylindrospermopsin in vivo, but that a thrombohemorrhagic phenomenon is observed in a proportion of dosed animals. It has been shown that the toxin can be metabolized in vivo and that a bound metabolite occurs in the liver. Cytotoxicity experiments using cell cultures show that cylindrospermopsin is more cytotoxic to isolated rat liver hepatocytes than to other cell types (37). Risk assessment calculations show that guideline values for cylindrospernopsin in drinking water should lie in the low microgram per liter range (11).

\section{Lyngbyatoxin A, aplysiatoxin and debromoaplysiatoxin}

All these three compounds are metabolites of Lyngbya majuscula, filamentous blue-green alga with worldwide distribution throughout tropical and subtropical regions. Since the first reports in the late 1950's in Hawaii and later in Okinawa, swimmers coming into contact with this cyanobacterium have contracted acute dermatitis. From the over forty unique biologically active chemicals isolated from this species, three toxins, debromoaplysiatoxin, aplysiatoxin, and lyngbyatoxin $\mathrm{A}$, have been found to be the major cause of dermatitis (6). Aplysiatoxin and its debromylated derivative are cyclic ethers, lybgbyatoxin is indole alkaloid (Fig. 7). These three toxins are all tumor promoters, binding to phorbol ester receptors leading to the activation of protein kinase C $(12,22)$.
Fig. 7. Chemical structures of aplysiatoxin, debromoaplysiatoxin and lyngbyatoxin

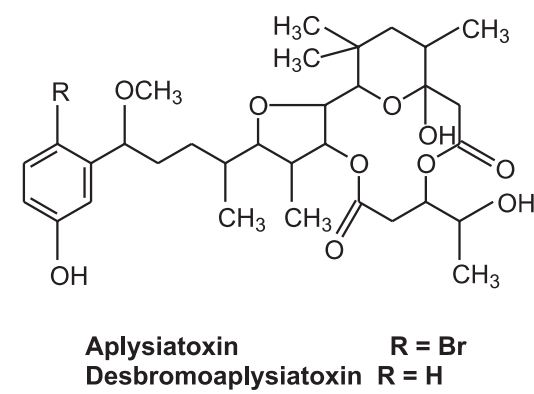<smiles>C=CC(C)(CCC=C(C)C)c1ccc(N(C)C(C(=O)NC(CO)CC2=CNc3ccc2cc3)C(C)C)c2c1=CC=2</smiles>

Lyngbyatoxin

\section{Cyanotoxins and water quality}

The potential for contamination of drinking water by blue-green algal toxins has resulted in the Australian authorities, and the World Health Organization (WHO) setting up working parties to develop water quality guidelines. These will specify 'safe' concentrations of these algal toxins in drinking water. The WHO guidelines are not compulsory, but act as a basis for governments to enact legislation on water quality. They will also provide guidance to public and private water supply authorities on the monitoring and safe concentrations of these toxins in drinking water. In the Czech Republic the problem of cyanobacterial contamination of water sources is not so meaningful. The huge amount of information about problems with Cyanobacteria in the Czech Republic is possible to obtain on the Internet address (18). It is clear that as human populations increase, so will rise the potential for toxic algal blooms. It is likely that both ecological measures to improve water quality and improved water treatment methods will be needed in the future.

\section{Cyanotoxins as scientific tool}

Neurotoxic active cyanotoxins are used very often as a research tool in biochemistry, neurobiology and electrophysiology $(8,43)$ and hepatotoxic active cyanotoxins are namely exploit in the studies of cytoskeletar organization of different cells $(21,44)$. Possibilities of cyanotoxins as research tool are not embraced yet. 


\section{Cyanotoxins as chemical warfare or bioterrorism device}

The toxicity of the major part of cyanotoxin is comparable with highly toxic chemical warfare compounds (11) and may be theoretically misused as weapons. Biological weapons are an important part of the level of international threat. Technological development has made biological weapon production relatively simple and cheap, and although a UN convention from 1972 bans biological weapons, governments as well as non-governmental organisations or individuals have developed biological weapons for offensive use in war or terrorism (31).

\section{Cyanotoxins and other Cyanobacteria products as possible therapeutics}

Most of cyanotoxins, such as the anatoxins and saxitoxins, will probably only be useful as biochemical research tools. A few, however, have the potential for development into useful commercial products. For example, some microcystins, shows impressive activity against a broad spectrum of solid tumors implanted in mice (26). Some compounds isolated from freshwater cyanobacteria have the anti-HIV activity and are also active against other retroviruses such as herpes simplex virus (HSV) (36). Antileukemic activity has been observed at debromoaplysiatoxin which has been isolated from Lyngbya gracilis. This compound also has dermonecrotic activity and may be the dermatitis-producing substance in L. majuscula, the causative agent of "swimmers' itch“ outbreaks in Hawaiian waters (25).

\section{Cyanobacteria as a source of further compounds}

Cyanobacteria may be a source of some further compounds in the future, such as the phycocyanin pigments. These pigments contain open chain tetrapyrroles with possible scavenging properties and antioxidant and antiinflammatory properties (34). Phycocyanin is also a very effective antioxidant protector of human erythrocytes against lysis by peroxyl radical (35). Other biologically active compounds isolated from Cyanobacteria are different polysaccharides with anti-inflammatory (14) and anti-HIV properties (36).

\section{Conclusions}

Cyanobacteria, formerly called "blue-green algae“, are relatively simple, primitive life forms closely related to bacteria and should not be mistaken for true algae, although they are in many respects ecologically similar. Cyanobacteria are found throughout the world in terrestrial, freshwater and marine habitats. Nutrient-rich bodies of water such as eutrophic lakes, agricultural ponds, or catch basins, may support a rapid growth of cyanobacteria. When conditions are good, a clear design of water can become very turbid with a green, blue-green or reddish-brown growth within just a few days. It is the freshwater habitat that typically experiences a cyanobacteria "bloom“. Sometimes blooms may produce toxins that are potentially lethal to animals, including humans. Some genera of cyanobacteria account for the vast majority of toxic blooms produced chemically interesting and toxicologically important compounds, cyanotoxins. Well-known cyanotoxins can be divided into neurotoxic anatoxins and saxitoxins and hepatotoxic microcystins, nodularin, cylindrospermopsin, aplysiatoxin and lyngbyatoxin. Algal toxins represent a major source of poisonings due to drinking water contamination and seafood consumption. Most classes of algal toxins are neurotoxins, while others target protein phosphatases, critical regulators of signal transduction pathways. Most algal toxins of human health significance are characterized by their high toxic potency and consist of suites of related congeners. The metabolic conversion, bioaccumulation, and food web transfer of the cyanobacterial toxins are incompletely understood in many cases. These characteristics make the analysis of cyanotoxins difficult and the determination of human health risk complex. Cyanotoxins represent only a small percentage of the thousands of compounds produced by microalgae, specifically those whose selective interaction with receptors in mammalian systems results in illness. Since the genes involved in toxin prodution have not been identified for any algal species, it is impossible currently to determine whether the capacity for toxin production is present, but silenced, in non-toxic varieties. As the molecular biology of microalgae becomes better understood, these questions will become answerable.

\section{References}

1. Andrinolo D, Michea LF, Lagos N. Toxic effects, pharmacokinetics and clearance of saxitoxin, a component of paralytic shellfish poison (PSP), in cats. Toxicon 1999;37:447-64.

2. Beattie KA, Kaya K, Codd GA. The cyanobacterium Nodularia PCC 7804, of freshwater origin, produces [L-Har2]nodularin. Phytochemistry 2000;54:57-61.

3. Brittain S, Mohamed ZA, Wang J, Lehmann VK, Carmichael WW, Rinehart KL. Isolation and characterization of microcystins from a river nile strain of oscillatoria tenuis agardh ex gomont. Toxicon 2000;38:1759-7.

4. Bryant DA. The Molecular Biology of Cyanobacteria. Kluwer Academic Publishers, 1994:916.

5. Byth S. Palm Island mystery disease. Med J Aust 1980;2:40-2

6. Cardellina JH, Marner FJ, Moore RE. Seaweed dermatitis: structure of lyngbyatoxin A. Science 1979;204:193-5.

7. Carmichael WW. The Cyanotoxins. Ed by CA. Callow, London: Academic Press, 1997:Adv Botan Res Vol. 27.

8. Catterall WA. Molecular properties of sodium and calcium channels. J Bioenerg Biomembr 1996;28:219-30

9. Codd GA. Cyanobacterial toxins, the perception of water quality, and the prioritisation of eutrophication control. Ecolog Engineering 2000;16:51-60.

10. Dawson RM: The toxicology of microcystins. Toxicon 1998;36:953-62.

11. Duy TN, Lam PK, Shaw GR, Connell DW. Toxicology and risk assessment of freshwater cyanobacterial (blue-green algal) toxins in water. Rev Environ Contam Toxicol 2000;163:113-85.

12. Eliasson L, Kallin B, Patarroyo M, Klein G, Fujiki H, Sugimura T. Activation of the EBV-cycle and aggregation of human blood lymphocytes by the tumor promoters teleocidin, lyngbyatoxin $\mathrm{A}$, aplysiatoxin and debromoaplysiatoxin. Int J Cancer 1983;31:7-11.

13. Falconer IR. Eutrophication by toxic blue-green algae. An increasing hazard in Australia, Aust Biologist 1988;1:10-2.

14. Garbacki N, Gloaguen V, Damas J, Hoffmann L, Tits M, Angenot L. Inhibition of croton oil-induced oedema in mice ear skin by capsular polysaccharides from cyanobacteria. Naunyn Schmiedebergs Arch Pharmacol 2000;361:460-4. 
15. Hemscheidt T, Rapala J, Sivonen K, and Skulberg O: Biosynthesis of anatoxina in Anabaena flos-aquae and homoanatoxin-a in Oscillatoria formosa. J Chem Soc Chem. Commun 1995;13:61-62.

16. http://www.chm.bris.ac.uk/motm/antx/antxh.htm)

17. http://www3.ncbi.nlm.nih.gov/htbin-post/Taxonomy/wgetorg

18. http://www.sinice@sinice.cz

19. Hyde EG, Carmichael WW: Anatoxin-a(s), a naturally occurring organophosphate, is an irreversible active site-directed inhibitor of acetylcholinesterase (EC 3.1.1.7). J Biochem Toxicol 1991;6:195-201.

20. Jochimsen EM, Carmichael WW, An JS et al. Liver failure and death after exposure to microcystins at a hemodialysis center in Brazil. $\mathrm{N}$ Engl $\mathrm{J}$ Med 1998:338:873-8

21. Khan SA, Wickstrom ML, Haschek WM, Schaeffer DJ, Ghosh S, Beasley VR. Microcystin-LR and kinetics of cytoskeletal reorganization in hepatocytes, kidney cells, and fibroblasts. Nat Toxins 1996;4:206-14

22. Kozikowski AP, Shum PW, Basu A, Lazo JS. Synthesis of structural analogues of lyngbyatoxin A and their evaluation as activators of protein kinase C. J Med Chem 1991;34:2420-30.

23. Lagos N, Onodera H, Zagatto PA, Andrinolo D, Azevedo SM, Oshima Y. The first evidence of paralytic shellfish toxins in the fresh water cyanobacterium Cylindrospermopsis raciborskii, isolated from Brazil Toxicon 1999;37:1359-73.

24. Molloy L, Wonnacott S, Gallagher T, Brough PA, Livett BG. Anatoxin-a is a potent agonist of the nicotinic acetylcholine receptor of bovine adrenal chromaffin cells. Eur J Pharmacol 199;289:447-53.

25. Mynderse JS, Moore RE, Kashiwagi M, Norton TR. Antileukemia activity in the Osillatoriaceae: isolation of Debromoaplysiatoxin from Lyngbya. Science 1977;196:538-40

26. Nishiwaki R, Ohta T, Sueoka E et al. Two significant aspects of microcystin-LR specific binding and liver specificity. Cancer Lett 1994:83:283-9.

27. Ohtani, Moore RE, Runnegar MTC. Cylindrospermopsin: a potent hepatotoxin from the blue-green alga Cylindrospermopsis raciborskii. J A Chem Soc 1992;114:7942-4

28. Onodera H, Satake M, Oshima Y, Yasumoto T, Carmichael WW. New saxitoxin analogues from the freshwater filamentous cyanobacterium Lyngbya wollei. Nat Toxins 1997;5:146-51.

29. Park HD, Watanabe MF, Harda K et al. Hepatotoxin (microcystin) and neurotoxin (anatoxin-a) contained in natural blooms and strains of cyanobacteria from Japanese freshwaters. Nat Toxins 1993;1:353-60.

30. Patočka J. Smrtící cyanobakterie a jejich toxiny. Bull Čs Spol Biochem Mol Biol 2000;28:21-3.

31. Patočka J, Fusek J. Toxis and their present military significance (In Czech). Voj Zdrav Listy 2000;69:70-6.

32. Rinehart KL, Harada K, Namikoshi M, Chen C,Harvis CA: Nodularin, microcystin and the configuration of Adda. J Am Chem Soc 110;25:8557-8.

33. Rippka R, Deruelles J, Waterbury JB, Herdman M, Stanier RY. Generic assignments, strain histories and properties of pure cultures of cyanobacteria. J Gen Microbiol 1997;111:1-61

34. Romay C, Armesto J, Remirez D, Gonzalez R, Ledon N, Garcia I. Antioxidant and anti-inflammatory properties of C-phycocyanin from blue-green algae. Inflamm Res 1998;47:36-41.

35. Romay C, Gonzalez R. Phycocyanin is an antioxidant protector of human eryth rocytes against lysis by peroxyl radicals. J Pharm Pharmacol 2000;52:367-8.

36. Schaeffer DJ, Krylov VS. Anti-HIV activity of extracts and compounds from algae and cyanobacteria. Ecotoxicol Environ Saf 2000;45:208-27.

37. Shaw GR, Seawright AA, Moore MR, Lam PK. Cylindrospermopsin, a cyanobacterial alkaloid: evaluation of its toxicologic activity. Ther Drug Monit 2000;22:89-92.

38. Sivonen K, Kononen K, Carmichael WW et al. Occurrence of the hepatotoxic cyanobacterium Nodularia spumigena in the Baltic Sea and structure of the toxin. Appl Environ Microbiol 1989;55:1990-5.

39. Spassova M., Mellor IR, Petrov AG et al. Pores formed in lipid bilayers and in native membranes by nodularin, a cyanobacteral toxin. Eur Biophys J 1995;24:6976.

40. Steffensen D, Burch M, Nicholson B, Drikas M, Baker P. Management of toxic Blue-Green algae (cyanobacteria) in Australia. Environ Toxicol 1999;14:183-95.

41. Šmarda J, Komárek J, Ćáslavská J, Hübel M. The Nodularia studies 1. Introduction, fine structure. Arch Hydrobiol 1988;Suppl. 80(Algological Studies 50-53):109-29.

42. Thomas P, Stephens M, Wilkie G et al. (+)-Anatoxin-a is a potent agonist at neuronal nicotinic acetylcholine receptors. J Neurochem 1993;60:2308-11

43. Valentine WM, Schaeffer DJ, Beasley VR. Electromyographic assessment of the neuromuscular blockade produced in vivo by anatoxin-a in the rat. Toxicon 1991;29:347-57.
44. Wonnacott S, Swanson KL, Albuquerque EX, Huby NJ, Thompson P, Gallagher T. Homoanatoxin: a potent analogue of anatoxin-A. Biochem Pharmacol 1992;43:419-23.

45. Yoshizawa S, Matsushima R, Watanabe MF et al. Inhibition of protein phosphatases by microcystins and nodularin associated with hepatotoxicity. J Cancer Res Clin Oncol 1990;116:609-14.

46. Wickstrom ML, Khan SA, Haschek WM et al. Alterations in microtubules, intermediate filaments, and microfilaments induced by microcystin-LR in cultured cells. Toxicol Pathol 199;23:326-37.

Submitted March 2001.

Accepted July 2001.

Prof. RNDr. Jiří Patočka, DrSc., Purkyně Military Medical Academy,

Department of Toxicology, 50001 Hradec Králové, Czech Republic. E-mail: patocka@pmfhk.cz 